\title{
Integrated pest management of crucifer crops against clubroot (Plasmodiophora brassicae) on crucifers crops cultivation
}

\author{
Integrowana ochrona roślin kapustowatych przed kiłą \\ (Plasmodiophora brassicae)
}

\author{
Józef Robak, Anna Czubatka, Agnieszka Czajka
}

\section{Summary}

On soils heavy contaminated with Plasmodiophora brassicae growing any susceptible crop of brassicae is impossible even using fumigation method involving the use of calcium cyanamide or dazomet. The satisfactory results suggested that resistant crucifers might effectively reduce numbers of resting spores of $P$. brassicae in soils. The total lack of disease symptoms was achieved when used disinfection with calcium cyanamide (Perlka 1,000 kg/ha) and sowing resistant winter oilseed cultivar Mendel F1 and Alister F1.

Key words: Plasmodiophora brassicae; catch crops; calcium cyanamide; integrated pest management

\section{Streszczenie}

Uprawa podatnych roślin kapustowatych na glebach silnie zasiedlonych przez Plasmodiophora brassicae z zastosowaniem cyjanamidu wapniowego jako środka dezynfekcyjnego nie daje skutecznej ochrony przed chorobą. Z przeprowadzonych badań wynika, że uprawa odpornych roślin kapustowatych na zakażonej glebie znacznie obniża stopień zasiedlenia jej przez $P$. brassicae. Najwyższy stopień obniżenia stopnia zasiedlenia $P$. brassicae uzyskano po uprawie odpornych odmian rzepaku ozimego Mendel F1 i Alister F1. Efekt biofumigacji z zastosowaniem odpornych roślin chwytnych był zbliżony do fumigacji chemicznej z zastosowaniem cyjanamidu wapniowego w postaci nawozu azotowo-wapniowego (Perlka $1000 \mathrm{~kg} / \mathrm{ha}$ ).

Słowa kluczowe: Plasmodiophora brassicae; rośliny chwytne; cyjanamid wapnia; integrowane zwalczanie

\author{
$\overline{\text { Instytut Ogrodnictwa }}$ \\ Zakład Ochrony Roślin Warzywnych \\ Pracownia Fitopatologii \\ Konstytucji 3 Maja 1/3, 96-100 Skierniewice \\ jozef.robak@inhort.pl; anna.czubatka@inhort.pl; agnieszka.czajka@inhort.pl
}




\section{Wstęp / Introduction}

Sprawca najgroźniejszej choroby roślin kapustowatych - kiła kapusty (Plasmodiophora brassicae) jest organizmem biotroficznym występującym w glebie, powodującym znaczne straty ekonomiczne w uprawach warzyw kapustnych oraz towarowych plantacjach rzepaku w Polsce i na świecie (Robak i wsp. 2008). Epidemiczny charakter występowania tej choroby w Polsce i na świecie staje się czynnikiem limitującym uprawę roślin kapustowatych. Główną przyczyną tego zjawiska jest monokulturowy charakter uprawy i nieprzestrzeganie podstawowych zasad zmianowania tych roślin. P. brassicae jest organizmem endemicznie występującym $\mathrm{w}$ glebach torfowych (torfy niskie), a także w torfowiskach wysokich eksploatowanych do produkcji substratów torfowych przeznaczonych do produkcji rozsad warzyw kapustnych (Robak 1981, 2010). Patogen ten poraża system korzeniowy roślin żywicielskich. Występujące w glebie zarodniki przetrwalnikowe $P$. brassicae pod wpływem wydzielin korzeniowych roślin żywicielskich wytwarzają zarodniki pływkowe, które po wniknięciu do komórek włośnikowych i komórek korzeni wypełniają je treścią plasmodium. Komórki systemu korzeniowego tracą wówczas swoją funkcję życiową pobierania składników pokarmowych i wody, powiększają swoją wielkość i liczbę (hipertrofia i hiperplasia) tworząc galasowate wyrośla. Porażone rośliny w szybkim tempie więdną i zamierają. Warunkami sprzyjającymi rozwojowi choroby jest wysoka wilgotność gleby, jej kwaśny odczyn $\mathrm{pH}$ poniżej 6,0 oraz temperatura $22-25^{\circ} \mathrm{C}$ (Robak 1981, 1991; Nowicki 1984). Patogen ten posiada około 200 gatunków roślin żywicielskich: pospolite chwasty $\mathrm{z}$ rodziny Brassicaceae, np.: tobołki polne, tasznik pospolity, gęsiówka piaskowa, gorczyca polna (Robak 1981). Zarodniki przetrwalnikowe $P$. brassicae mają zdolność przetrwania $\mathrm{w}$ glebie do 6-8 lat bez obecności żywicieli. Zarodniki infekcyjne - zoospory są ruchliwe w środowisku wodnym, dlatego sprawca choroby ma dużą zdolność rozprzestrzeniania się z wodą na duże obszary poprzez systemy melioracyjne. W Instytucie Ogrodnictwa w Skierniewicach kontynuowane są badania nad doskonaleniem i poszukiwaniem nowych, efektywnych metod ochrony roślin kapustowatych przed kiłą (Robak i Gidelska 2009, 2011). Podjęto także badania nad możliwością obniżania progu szkodliwości $P$. brassicae $\mathrm{w}$ glebach silnie zasiedlonych $\mathrm{z}$ zastosowaniem uprawy roślin chwytnych. Roślinami chwytnymi mogą być podatne gatunki roślin żywicielskich, jak również odporne na $P$. brassicae gatunki z rodziny Brassicaceae. W badaniach użyto rośliny żywicielskie podatne na $P$. brassicae: gorczycę biała i rzepak ozimy odmiana Pamela oraz odporne: rzepak ozimy odmiany: Mendel F1 i Alister F1, rzodkiew oleistą odmiana Romesa, rzodkiew czarną odmiana Murzynka i kapustę pekińską odmiana Bilko F1, a także jeden gatunek rośliny nieżywicielskiej - rajgras roczny (Lolium perenne) (Yamagishi i wsp. 1986). Nasiona tych roślin wysiano do gleby silnie zasiedlonej przez $P$. brassicae zgodnie $\mathrm{z}$ zasadami agrotechniki $\mathrm{w}$ celu zainicjowania kiełkowania zarodników przetrwalnikowych w glebie. Poprzez uprawę tych roślin można uzyskać całkowite lub częściowe uwolnienie zakażonej gleby od patogena polegające na przerwaniu jego pełnego cyklu biologicznego. Metoda uprawy roślin chwytnych na glebach silnie zasiedlonych przez $P$. brassicae może stanowić w praktyce jedyną i najbardziej efektywną metodę zwalczania kily kapusty w wielkoobszarowych uprawach rzepaku i warzyw kapustnych. Z przeprowadzonych badań wynika, że nawet jednokrotna uprawa na glebie silnie zasiedlonej przez sprawcę choroby rośliny podatnej - gorczycy białej przez ściśle określony okres istotnie obniżyła stopień zasiedlenia gleby przez $P$. brassicae. Okres uprawy i fazy rozwojowej rośliny podatnej - gorczycy białej został we wstępnych badaniach ustalony jako faza tworzenia zielonego paka kwiatowego (BBCH 57-59).

W Instytucie Ogrodnictwa w Skierniewicach trwaja badania nad opracowaniem integrowanej ochrony roślin kapustowatych przed $P$. brassicae z wykorzystaniem uprawy roślin „chwytnych” i nawozu azotowo-wapniowego (cyjanamid wapnia).

\section{Materiały i metody / Materials and methods}

\section{Doświadczenie 1.}

Badania prowadzono w latach 2011-2012, w warunkach doświadczeń mikropoletkowych o powierzchni $1 \mathrm{~m}^{2}$ w układzie bloków losowanych w 6 powtórzeniach z wykorzystaniem różnych roślin „chwytnych” zestawionych w tabeli 1.

W doświadczeniu użyto kilku gatunków roślin żywicielskich $P$. brassicae, do których należą: podatne na $P$. brassicae: gorczyca biała, rzepak ozimy odmiana Pamela, odporne: rzepak ozimy odmiana Alister F1, rzepak ozimy odmiana Mendel F1, rzodkiew oleista odmiana Romesa, rzodkiew czarna odmiana Murzynka, kapusta pekińska odmiana Bilko F1 oraz roślina nieżywicielska rajgras roczny (L. perenne).

Gleba polowa umieszczona w mikropoletkach została sztucznie zasiedlona zarodnikami $P$. brassicae o zagęszczeniu $4 \times 10^{7}$ na $1 \mathrm{ml}$ gleby. Nasiona badanych roślin chwytnych wysiano rzutowo. Wszystkie gatunki roślin chwytnych z wyjątkiem gorczycy białej, podatnej na $P$. brassicae rosły do początku sierpnia, a gorczycy białej tylko do fazy tworzenia zielonego pąka kwiatowego (BBCH 57-59). Po tym okresie rośliny wykaszano i dokładnie przyorano, tak aby nie pozostawić na powierzchni gleby nawet pojedynczych, wegetujących roślin. Okres wegetacji podatnej na $P$. brassicae gorczycy był wystarczający do zaindukowania cyklu biologicznego sprawcy choroby, lecz przerywał w optymalnym momencie przejście jego pełnego cyklu.

W przypadku wegetacji pozostałych roślin chwytnych dokonano także ich wykoszenia i dokładnego przekopania gleby do głębokości $15-18 \mathrm{~cm}$ oraz przygotowania poletek do ponownego siewu nasion roślin testowych. Roślinami testowymi (wskaźnikowymi) były dwie odmiany rzepaku ozimego: odporny Alister F1 oraz podatny Pamela. Do każdego z poletek wysiewano rzutowo nasiona, do 3 poletek rośliny podatnej i do 3 poletek nasiona rośliny odpornej.

Po 35 dniach od siewu nasion roślin testowych dokonano na 50\% roślin z każdego poletka oceny korzeni na obecność objawów choroby. Przy ocenie występowania 
Tabela 1. Schemat doświadczenia mikropoletkowego z uprawą roślin chwytnych

Table 1. The experimental design of micro plots trial of catch crops

Skierniewice 2011-2012

\begin{tabular}{l|l}
\hline \multicolumn{1}{c|}{\begin{tabular}{c}
\multicolumn{1}{c}{ Roślina chwytna } \\
Catch crops
\end{tabular}} & \multicolumn{1}{c}{\begin{tabular}{c}
\multicolumn{1}{c}{ Faza fenologiczna likwidacji roślin (BBCH) } \\
Period of cultivation
\end{tabular}} \\
\hline $\begin{array}{l}\text { Kontrola (czarny ugór) } \\
\text { Check (black fallow) }\end{array}$ & $\begin{array}{l}\text { bez roślin okrywowych } \\
\text { withoutplants }\end{array}$ \\
\hline $\begin{array}{l}\text { Gorczyca biała } \\
\text { White mustard }\end{array}$ & $\begin{array}{l}\text { do fazy pąka jeden raz (BBCH 57-58) } \\
\text { single cropping up to first flower bud formation (BBCH 57-58) }\end{array}$ \\
\hline $\begin{array}{l}\text { Gorczyca biała } \\
\text { White mustard }\end{array}$ & $\begin{array}{l}\text { do fazy pąka dwukrotnie (BBCH 57-58 ) } \\
\text { double cropping up to first flower bud formation (BBCH 57-58 ) }\end{array}$ \\
\hline $\begin{array}{l}\text { Rzepak ozimy odmiana Alister F1 } \\
\text { Winter rape cultivar Alister F1 }\end{array}$ & $\begin{array}{l}\text { cztery miesiące wzrostu roślin (BBCH 71) } \\
\text { single cropping four month growing plants (BBCH 71) }\end{array}$ \\
\hline $\begin{array}{l}\text { Rzodkiew oleista odmiana Romesa } \\
\text { Oil seed radish cultivar Romesa }\end{array}$ & $\begin{array}{l}\text { cztery miesiące wzrostu roślin (BBCH 71) } \\
\text { single cropping four month growing plants (BBCH 71) }\end{array}$ \\
\hline $\begin{array}{l}\text { Rzodkiew czarna odmiana Murzynka } \\
\text { Black radish cultivar Murzynka }\end{array}$ & $\begin{array}{l}\text { cztery miesiące wzrostu roślin (BBCH 71) } \\
\text { single cropping four month growing plants (BBCH 71) }\end{array}$ \\
\hline $\begin{array}{l}\text { Kapusta pekińska odmiana Bilko F1 } \\
\text { Chinese cabbage cultivar Bilko F1 }\end{array}$ & $\begin{array}{l}\text { cztery miesiące wzrostu roślin (BBCH 71) } \\
\text { single cropping four month growing plants (BBCH 71) }\end{array}$ \\
\hline $\begin{array}{l}\text { Rzepak ozimy odmiana Mendel F1 } \\
\text { Winter rape cultivar Mendel F1 }\end{array}$ & $\begin{array}{l}\text { cztery miesiące wzrostu roślin (BBCH 71) } \\
\text { single cropping four month growing plants (BBCH 71) }\end{array}$ \\
\hline $\begin{array}{l}\text { Rajgras roczny } \\
\text { Annual ryegrass }\end{array}$ & $\begin{array}{l}\text { cztery miesiące wzrostu roślin (BBCH 71) } \\
\text { single cropping four month growing plants (BBCH 71) }\end{array}$ \\
\hline $\begin{array}{l}\text { Kontrola - gorczyca biała } \\
\text { Check - white mustard }\end{array}$ & $\begin{array}{l}\text { cztery miesiące wzrostu roślin do wytworzenia nasion (BBCH 71) } \\
\text { single cropping up to seeds formation (BBCH 71) }\end{array}$ \\
\hline
\end{tabular}

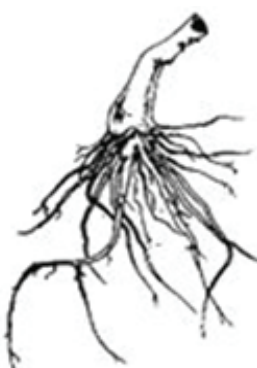

0

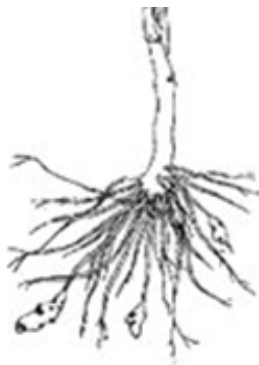

1

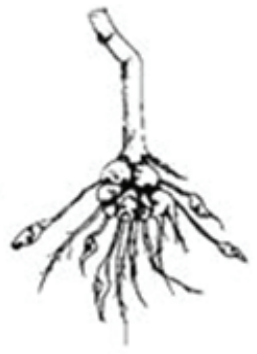

2

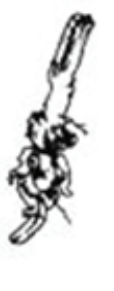

3

Rys. 1. P. brassicae - skala oceny porażenia korzeni $\left(0-3^{\circ}\right)$

Fig. 1. P. brassicae - rating scale for evaluation of diseased root symptoms

0 - brak objawów choroby $(0)$ - no symptoms

1 - małe, pojedyncze wyrośla (1) - small single nodular galls

2 - większe wyrośla na korzeniach bocznych (2) - larger nodular or spherical galls

3 - duże wyrośla na korzeniu głównym i szyjce korzeniowej (3) - large gall sexten dingin to hypocotyl

kiły posługiwano się skalą bonitacyjną $0-3^{\circ}[\mathrm{EPPO} \mathrm{PP}$ 1/39 (2)], gdzie 0 - oznacza brak objawów choroby, 3 duże wyrośla na korzeniu głównym i szyjce korzeniowej (rys. 1).

\section{Doświadczenie 2.}

Doświadczenie przeprowadzono w roku 2011, w mikropoletkach wypełnionych sztucznie zasiedloną przez
$P$. brassicae glebą polową $\left(4 \times 10^{7}\right.$ zarodników na $1 \mathrm{ml}$ gleby). Mikropoletka stanowiły betonowe kręgi o powierzchni $1 \mathrm{~m}^{2}$ w układzie bloków losowanych w 4 powtórzeniach. Obiektem badań był nawóz azotowo-wapniowy Perlka (cyjanamid wapnia) posiadający jednocześnie właściwości dezynfekcyjne. Badano trzy dawki nawozu Perlka odpowiadające: 500, 1000 i $1500 \mathrm{~kg} / \mathrm{ha}$ (tab. 2) (Dixon i Wilson 1983). Nawóz rozsiewano równomiernie na powierzchni gleby i mieszano do głębokości około 
Tabela 2. Schemat doświadczenia dotyczącego stosowania cyjanamidu wapnia i wybranych odmian rzepaku ozimego na uwolnienie gleby od P. brassicae

Table 2. The experimental design on the application of calcium cyanamide and selected varieties of winter oilseed rape on the release of soil from $P$. brassicae

Skierniewice 2011

\begin{tabular}{|c|c|c|}
\hline $\begin{array}{l}\text { Badane obiekty } \\
\text { Soil treatments }\end{array}$ & $\begin{array}{l}\text { Dawka produktu }[\mathrm{kg} / \mathrm{ha}] \\
\text { Dose of product }[\mathrm{kg} / \mathrm{ha}]\end{array}$ & $\begin{array}{l}\text { Rośliny testowe } \\
\text { Test plants }\end{array}$ \\
\hline $\begin{array}{l}\text { Kontrola } 1 \\
\text { Check } 1\end{array}$ & $\begin{array}{l}\text { nietraktowana } \\
\text { non treatment }\end{array}$ & $\begin{array}{l}\text { rzepak ozimy, podatny odmiana Pamela } \\
\text { oilseed rape susceptible host cultivar Pamela }\end{array}$ \\
\hline $\begin{array}{l}\text { Kontrola } 2 \\
\text { Check } 2\end{array}$ & $\begin{array}{c}\text { nietraktowana } \\
\text { non treatment }\end{array}$ & $\begin{array}{l}\text { rzepak ozimy, odporny odmiana Alister F1 } \\
\text { oilseed rape resistance host cultivar Alister F1 }\end{array}$ \\
\hline $\begin{array}{l}\text { Kontrola } 3 \\
\text { Check } 3\end{array}$ & $\begin{array}{l}\text { nietraktowana } \\
\text { non treatment }\end{array}$ & $\begin{array}{l}\text { rzepak ozimy, odporny odmiana Mendel F1 } \\
\text { oilseed rape resistance host cultivar Mendel F1 }\end{array}$ \\
\hline Perlka & $\begin{array}{c}1000 \mathrm{~kg} / \mathrm{ha} \text { - dezynfekcja gleby } \\
1000 \mathrm{~kg} / \mathrm{ha} \text { soil disinfection }\end{array}$ & $\begin{array}{c}\text { rzepak odporny, odmiana Alister F1 } \\
\text { oilseed rape resistance host cultivar Alister F1 }\end{array}$ \\
\hline Perlka & $\begin{array}{c}1000 \mathrm{~kg} / \mathrm{ha} \text { - dezynfekcja gleby } \\
1000 \mathrm{~kg} / \mathrm{ha} \text { soil disinfection }\end{array}$ & $\begin{array}{c}\text { rzepak odporny, odmiana Mendel F1 } \\
\text { oilseed rape resistance host cultivar Mendel F1 }\end{array}$ \\
\hline Perlka & $\begin{array}{c}1000 \mathrm{~kg} / \mathrm{ha} \text { - dezynfekcja gleby } \\
1000 \mathrm{~kg} / \mathrm{ha} \text { soil disinfection }\end{array}$ & $\begin{array}{c}\text { rzepak podatny, odmiana Pamela } \\
\text { oilseed rape susceptible host cultivar Pamela }\end{array}$ \\
\hline Perlka & $\begin{array}{c}1500 \mathrm{~kg} / \mathrm{ha} \text { - dezynfekcja gleby } \\
1500 \mathrm{~kg} / \mathrm{ha} \text { soil disinfection }\end{array}$ & $\begin{array}{c}\text { rzepak podatny, odmiana Pamela } \\
\text { oilseed rape susceptible host cultivar Pamela }\end{array}$ \\
\hline Perlka & $\begin{array}{l}500 \mathrm{~kg} / \mathrm{ha} \text { - dezynfekcja gleby } \\
500 \mathrm{~kg} / \mathrm{ha} \text { soil disinfection }\end{array}$ & $\begin{array}{c}\text { rzepak odporny, odmiana Alister F1 } \\
\text { oilseed rape resistance host cultivar Alister F1 }\end{array}$ \\
\hline
\end{tabular}

$10 \mathrm{~cm}$. Po 15 dniach od zastosowania nawozu Perlka do gleby wysiano nasiona trzech odmian rzepaku ozimego: odmianę podatną Pamela i dwie odmiany odporne: Mendel F1 i AlisterF1. Analogicznie, jak w doświadczeniu pierwszym ocenę zdrowotności systemu korzeniowego przeprowadzono po 35 dniach wzrostu roślin (BBCH 18). Porażenie korzeni kiłą oceniano przy pomocy skali bonitacyjnej $0-3^{\circ}$ [EPPO PP 1/39 (2)].

Wyniki opracowano analizą wariancji, istotność różnic oceniono testem Newmana-Keulsa.

\section{Wyniki i dyskusja / Results and discussion}

\section{Doświadczenie 1.}

$\mathrm{Na}$ podstawie uzyskanych wyników można wnioskować, iż wszystkie gatunki roślin chwytnych istotnie wpłynęły na obniżenie poziomu stopnia zasiedlenia gleby przez P. brassicae (tab. 3). Najwyższą efektywność

Tabela 3. Wpływ stosowania roślin „,chwytnych” na ograniczenie porażenia korzeni roślin testowych przez P. brassicae

Table 3. The effect of "catch crops" on the limitation of the test plants root infection by P. brassicae

Skierniewice 2012

\begin{tabular}{|c|c|c|c|c|}
\hline \multirow[t]{2}{*}{$\begin{array}{l}\text { Roślina chwytna } \\
\text { Catch crops }\end{array}$} & \multicolumn{2}{|c|}{$\begin{array}{l}\text { Średni stopień porażenia } \\
\mathrm{P} \text { O } \\
\text { Root-gall index range } 0-3^{\circ}\end{array}$} & \multicolumn{2}{|c|}{$\begin{array}{c}\text { \% roślin porażonych } \\
\text { P O } \\
\text { Percentage diseased plant }\end{array}$} \\
\hline & & $\mathrm{R}$ & S & $\mathrm{R}$ \\
\hline 1 & \multicolumn{2}{|c|}{2} & \multicolumn{2}{|c|}{3} \\
\hline $\begin{array}{l}\text { Kontrola (czarny ugór) } \\
\text { Check (black fallow) }\end{array}$ & $1,7 \mathrm{a}$ & $0,2 \mathrm{a}$ & 48 & 4 \\
\hline $\begin{array}{l}\text { Gorczyca biała (uprawa jednokrotna) }\left(^{*}\right) \\
\text { White mustard (single croping) }(*)\end{array}$ & $0,4 \mathrm{~b}$ & $0,1 \mathrm{ab}$ & 17 & 1 \\
\hline $\begin{array}{l}\text { Gorczyca biała (uprawa dwukrotna) }(*) \\
\text { White mustard (double croping) }(*)\end{array}$ & $0,7 \mathrm{~b}$ & $0,1 \mathrm{ab}$ & 29 & 3 \\
\hline $\begin{array}{l}\text { Rzepak ozimy odmiana Alister F1 } \\
\text { Oilseed rape cultivar Alister F1 }\end{array}$ & $2,6 \mathrm{a}$ & $0,1 \mathrm{ab}$ & 65 & 4 \\
\hline $\begin{array}{l}\text { Rzepak ozimy odmiana Mendel F1 } \\
\text { Oilseed rape cultivar Mendel F1 }\end{array}$ & $2,3 \mathrm{a}$ & $0 \mathrm{~b}$ & 73 & 0 \\
\hline $\begin{array}{l}\text { Rzepa oleista (Raphanus sativus) odmiana Romesa } \\
\text { Oil seed radish (Raphanus sativus) cultivar Romesa }\end{array}$ & $0,7 \mathrm{~b}$ & $0 \mathrm{~b}$ & 26 & 0 \\
\hline
\end{tabular}




\begin{tabular}{|c|c|c|c|c|}
\hline 1 & \multicolumn{2}{|c|}{2} & \multicolumn{2}{|c|}{3} \\
\hline $\begin{array}{l}\text { Czarna rzepa (Raphanus sativus) odmiana Murzynka } \\
\text { Black radish (Raphanus sativus) cultivar Murzynka }\end{array}$ & $2,2 \mathrm{a}$ & $0 \mathrm{~b}$ & 57 & 0 \\
\hline $\begin{array}{l}\text { Kapusta pekińska odmiana Bilko F1 } \\
\text { Chinese cabbage cultivar Bilko F1 }\end{array}$ & $0,2 \mathrm{~b}$ & $0,2 \mathrm{a}$ & 23 & 4 \\
\hline $\begin{array}{l}\text { Rajgras roczny (Lolium perenne) } \\
\text { Annual ryegrass (Lolium perenne) }\end{array}$ & $1,9 \mathrm{a}$ & $0 \mathrm{~b}$ & 57 & 0 \\
\hline $\begin{array}{l}\text { Kontrola - gorczyca biała } \\
\text { Check - white mustard }\end{array}$ & $1,8 \mathrm{a}$ & $0,1 \mathrm{ab}$ & 37 & 2 \\
\hline
\end{tabular}

Wartości liczbowe w kolumnach oznaczone tą samą literą nie różnią się istotnie przy $\mathrm{p}=0,05$, test Newmana-Keulsa

Newman-Keul's test; the mean numbers with this same letter are not significantly different at $\mathrm{p}=0.05$

$\mathrm{P}$ - roślina testowa podatna (rzepak ozimy odmiana Pamela)

$\mathrm{S}$ - suscsptible test plants (oilseed rape odmiana Pamela)

$\mathrm{O}$ - roślina testowa odporna (rzepak ozimy odmiana Alister F1)

$\mathrm{R}$ - resistant test plants (oilseed rape cultivar Alister F1)

(*) uprawa do fazy formowania paka (BBCH 57-58) - cultivation up to flower buds forming

obniżenia stopnia zasiedlenia uzyskano w obiekcie, gdzie rośliną chwytną była rzodkiew oleista odmiana Romesa oraz podatna odmiana gorczycy białej. Nawet jednokrotna uprawa na silnie zasiedlonej glebie podatnej rośliny gorczycy białej znacznie obniżyła stopień zasiedlenia gleby przez $P$. brassicae.

Uprawa gorczycy białej do fazy tworzenia zielonego pąka kwiatowego (BBCH 57-59) trwała w zależności od temperatury 3-5 tygodni i stanowiła optymalny okres do indukowania kiełkowania zarodników przetrwalnikowych sprawcy choroby, lecz nie pozwalała im na przejście pełnego cyklu rozwojowego. Z chwilą pocięcia roślin i ich dokładnego przyorania kończył się cykl biologiczny patogena bez wytworzenia kolejnych zarodników przetrwalnikowych stanowiących w przyszłości źródło infekcji roślin.

Odpowiednie gatunki roślin żywicielskich $P$. brassicae stwarzają realne możliwości efektywnej i naturalnej metody eliminowania sprawcy kiły kapusty w uprawach roślin warzywnych oraz towarowych plantacjach rzepaku. Istnieje jednak poważne zagrożenie uprawy podatnej rośliny żywicielskiej jaką jest gorczyca biała na zakażonej glebie, gdzie z chwilą opóźnienia terminu likwidacji tych roślin, np. przy niesprzyjających warunkach pogodowych i przejścia pełnego cyklu rozwojowego $P$. brassicae, nastąpi wytworzenie zarodników przetrwalnikowych. Najbardziej bezpieczną metodą eliminowania z gleby sprawcy kiły kapusty jest uprawa odpornych odmian, np. rzepaku lub kapusty pekińskiej, gdzie oprócz zamierzonego efektu obniżania stopnia zasiedlenia zakażonej gleby można uzyskać normalny plon handlowy rzepaku lub kapusty. Bezwzględnym warunkiem pełnego uzdrowienia zasiedlonej gleby przez $P$. brassicae jest zintegrowanie wielu czynników: przestrzeganie prawidłowego zmianowania z 4-letnią przerwą w uprawie roślin żywicielskich na tym samym polu, uprawa odmian odpornych i w szczególnych przypadkach, w uprawie warzyw kapustnych profilaktyczne stosowanie cyjanamidu wapniowego w określonej dawce lub innych dopuszczonych prawem pestycydów zapobiegawczych.

\section{Doświadczenie 2.}

Na podstawie przeprowadzonych badań stwierdzono, iż najwyższą skuteczność w obniżeniu stopnia zasiedlenia gleby przez $P$. brassicae uzyskano po zastosowaniu nawozu azotowo-wapniowego Perlka (cyjanamid wapnia) o właściwościach dezynfekcyjnych w dawce $1000 \mathrm{~kg} / \mathrm{ha}$ $\mathrm{w}$ połączeniu $\mathrm{z}$ uprawą rzepaku odpornego odmiana Mendel F1 (tab. 4).

Tabela 4. Wpływ dezynfekcji gleby cyjanamidem wapnia i stosowania wybranych odmian rzepaku ozimego na ograniczenie porażenia korzeni roślin testowych przez $P$. brassicae

Table 4. Effect of calcium cyanamide soil disinfection and use of selected varieties of oilseed rape to reduce the clubroot symptoms on the rootsof the test plants

Skierniewice 2011

\begin{tabular}{l|c|c}
\hline \multicolumn{1}{c|}{$\begin{array}{c}\text { Badane obiekty } \\
\text { Treatments }\end{array}$} & $\begin{array}{c}\text { Średnia skala porażenia } \\
\text { Root-gall index range } \\
0-3^{\circ}\end{array}$ & $\begin{array}{c}\text { \% roślin porażonych } \\
\text { Percentage diseased plants }\end{array}$ \\
\hline 1 & 2 & 3 \\
\hline $\begin{array}{l}\text { Kontrola 1 - rzepak podatny odmiana Pamela } \\
\text { Check 1 - oilseed rape susceptible cultivar Pamela }\end{array}$ & $3,0 \mathrm{a}$ & 100 \\
\hline $\begin{array}{l}\text { Kontrola 2 - rzepak odporny odmiana Alister F1 } \\
\text { Check 2 - oilseed rape resistance cultivar Alister F1 }\end{array}$ & $0,1 \mathrm{c}$ & 2 \\
\hline $\begin{array}{l}\text { Kontrola 3 - rzepak odporny odmiana Mendel F1 } \\
\text { Check 3 - oilseed rape resistant cultivar Mendel F1 }\end{array}$ & $0,1 \mathrm{c}$ & 4 \\
\hline
\end{tabular}




\begin{tabular}{l|c|c}
\hline \multicolumn{1}{c|}{1} & 2 & 3 \\
\hline $\begin{array}{l}\text { Perlka }-1000 \mathrm{~kg} / \mathrm{ha}, \text { rzepak odporny odmiana Alister F1 } \\
\text { Perlka }-1000 \mathrm{~kg} / \mathrm{ha} \text {, oilseed rape resistant cultivar Alister F1 }\end{array}$ & $0,1 \mathrm{c}$ & 2 \\
\hline $\begin{array}{l}\text { Perlka }-1000 \mathrm{~kg} / \mathrm{ha}, \text { rzepak odporny odmiana Mendel F1 } \\
\text { Perlka }-1000 \mathrm{~kg} / \mathrm{ha} \text {, winter rape resistant cultivar Mendel F1 }\end{array}$ & $0 \mathrm{c}$ & 0 \\
\hline $\begin{array}{l}\text { Perlka }-1000 \mathrm{~kg} / \mathrm{ha}, \text { rzepak podatny odmiana Pamela } \\
\text { Perlka }-1000 \mathrm{~kg} / \mathrm{ha} \text {, oilseed rape susceptible cultivar Pamela }\end{array}$ & $0,5 \mathrm{~b}$ & 19 \\
\hline $\begin{array}{l}\text { Perlka }-1500 \mathrm{~kg} / \mathrm{ha}, \text { rzepak podatny odmiana Pamela } \\
\text { Perlka }-1500 \mathrm{~kg} / \mathrm{ha} \text {, winter rape susceptible cultivar Pamela }\end{array}$ & $0,5 \mathrm{~b}$ & 22 \\
Perlka $-500 \mathrm{~kg} / \mathrm{ha}$, rzepak odporny odmiana Alister F1 & $0,1 \mathrm{c}$ & 3 \\
\hline
\end{tabular}

Wartości liczbowe w kolumnach oznaczone tą samą literą nie różnią się istotnie przy p =0,05, test Newmana-Keulsa

Newman-Keul's test; the mean numbers with the same letter are not significantly different at $\mathrm{p}=0.05$

\section{Wnioski / Conclusions}

1. Wszystkie gatunki roślin „chwytnych” istotnie wpłynęły na obniżenie stopnia zasiedlenia gleby przez P. brassicae.

2. Na polu w wysokim stopniu zasiedlonym przez $P$. brassicae wskazana jest metoda łączenia dezynfekcji chemicznej z uprawą odpowiednich roślin „chwytnych".

3. Odpowiednie gatunki roślin żywicielskich $P$. brassicae stwarzają realne możliwości efektywnej i naturalnej metody obniżania stopnia zagrożenia upraw roślin kapustowatych przed ich najgroźniejszą chorobą.

\section{Literatura / References}

Dixon G.R., Wilson F. 1983. Evaluation of calcium cyanamide for control of Plasmodiophora brassicae (clubroot). J. Ann. Appl. Biol. 102, Supplement: $50-51$.

EPPO Standards. 1997. Guidelines for the efficacy evaluation of plant protection products. Fungicides and bacteriocides. Vol. 2, 192 pp.

Nowicki B. 1984. Zróżnicowanie biologiczne Plasmodiophora brassicae Wor. w Polsce oraz podatność uprawianych roślin krzyżowych na wykryte patotypy grzyba. SGGW-AR, Warszawa 34: 5-17, 76 ss.

Robak J. 1981.Występowanie kiły kapusty na glebach torfowych oraz jej zwalczanie metodami chemicznymi. Praca doktorska. Instytut Warzywnictwa, Skierniewice, 123 ss.

Robak J. 1991. Zmienność patotypówPlasmodiophora brassicae Wor. występujących w Polsce i ich patogeniczność w stosunku do odmian i linii hodowlanych Brassica oleracea. Praca habilitacyjna nr 6. Instytut Warzywnictwa, Skierniewice, 61 ss.

Robak J., Gidelska A. 2009. Epidemiologia i nowe możliwości zwalczania Plasmodiophora brassicae Wor. - sprawcy kiły kapusty na roślinach kapustowatych w Polsce. [Epidemiology and new possibility of control of Plasmodiophora brassicae causal agent of clubroot of cruciferous crop in Poland]. Prog. Plant Prot./Post. Ochr. Roślin 49 (1): 268-274.

Robak J., Gidelska A. 2011. Ochrona warzyw kapustowatych przed chorobami w zróżnicowanym systemie produkcji. [Protection of brassicae crops against disease causal agents in a sustainable production system]. Prog. Plant Prot./Post. Ochr. Roślin 51 (1): 298-306.

Yamagishi H., Yoshikawa H., Ashizawa M., Hida K., Yoi S. 1986. Effects of resistant plants as catch crop on thereduction of resting spores of clubroot (Plasmodiophora brassicae Woron.) in soil. J. Japan Soc. Hort. Sci. 54: 460-466. 